\title{
Determinants of services trade agreements: Regulatory incidence and convergence
}

\author{
Peter Egger*and Anirudh Shingal ${ }^{\dagger}$
}

December 2013

\begin{abstract}
Given the rise of services preferentialism in the last decade and the importance of domestic regulation for services trade, this paper examines the role of regulatory incidence and convergence as determinants of services trade agreements (STAs). Our results suggest that regulation is an important determinant of STA membership. They also suggest that geography, common institutions and pre-existing trade matter more than economic size and factor endowments for addressing regulatory incidence and convergence in services negotiations. Finally, we find that countries displaying greater regulatory convergence and less restrictive regulation are also more likely candidates for reciprocal services liberalization.
\end{abstract}

JEL classification: F10, F13, F15

Key words: Services trade agreements; Economic determinants; STRI; Regulatory convergence

*ETH, Zurich (egger@kof.ethz.ch)

†World Trade Institute, University of Bern (anirudh.shingal@wti.org) 


\section{Introduction}

More than three decades of research on trade costs and goods trade unveiled fundamental insights into the determinants (Baier and Bergstrand, 2004), the relative magnitude and nature (Eaton and Kortum, 2002; Anderson and van Wincoop, 2003, 2004) and the consequences of barriers to cross-border transactions (Baier and Bergstrand, 2007, 2009; Bergstrand et al., 2013; Egger et al., 2011) of goods. However, much less is known about services trade and their impediments. Data on cross-border transactions of services became available only in the last decade, and data on service trade impediments have been collected and made available even more recently (for instance see Miroudot et al., 2012). Even though a cottage literature started evolving around the matter (see Francois and Hoekman, 2010, for a survey), key knowledge about fundamental drivers and consequences of service trade barriers is not available. This paper aims to bridge this gap by addressing the role of regulation in STA membership.

A striking feature of trade diplomacy in recent years has been the pace of preferential goods trade liberalization and rule-making. In the last decade, a similar trend has been observed regarding services trade. Of the 83 preferential trade agreements (PTAs) notified to the World Trade Organization (WTO) and in force prior to the year 2000, 73 (87.9\%) featured provisions dealing exclusively with trade in goods. Since then and up until August 2013, another 176 PTAs have come into force of which 105 (59.7\%) also include provisions on services trade $^{1}$. This development indicates the rising importance of services trade in general, the growing need felt by countries to place such trade on a firmer institutional and rulemaking footing, and the attractiveness of doing so on an expedited basis via preferential negotiating platforms (Sauvé and Shingal, 2011).

Unlike trade in goods, where the removal of border barriers retains significant negotiating traction, domestic regulation is the sole currency of negotiations in services trade (Mattoo and Sauvé, 2010). The importance and potentially trade- and investment-inhibiting impact of domestic regulation on service sector performance has received some attention in the literature (Kox and Nordås, 2007; Kox and Nordas, 2009). Regulatory incidence and heterogeneity have been shown to exert a significantly negative impact on bilateral services trade via Mode 3 ("Strict and different regulation discourages outward investment as local firms find it more difficult to enter foreign markets the more restricted they are at home," Kox and Nordas, 2009), which is the most dominant mode of service delivery (for instance

\footnotetext{
${ }^{1}$ As of 15 August 2013, the total number of STAs in force was 118. These included three alliances (MERCOSUR, EFTA and CARICOM) where an STA was negotiated after 2000 in addition to a pre-existing trade agreement in goods.
} 
see Magdeleine and Maurer, 2008; Hoekman and Kostecki, 2001).

However, the role of regulation, both incidence and convergence, in STA membership has not been studied. Are certain countries more likely candidates for negotiated regulatory convergence from a services trade perspective? Moreover are countries displaying greater regulatory convergence also more likely candidates for deeper integration agreements in services markets? The role of geography in trade-facilitating regulatory convergence in services has also not been explored.

In a bid to expand trade volumes, the objective of an STA is two-fold: first, to bring down the level and incidence of restrictive regulation in both markets and, second, to promote convergence, approximation (including through mutual recognition) and ultimately (but less frequently) to harmonize regulatory practices between trading partners. We would thus expect trading partners in a services accord to exhibit both lower incidence of regulation and regulatory heterogeneity compared to those not party to such an agreement. Conversely, the lower the incidence of restrictive regulation and regulatory heterogeneity in a trading dyad, the more likely it is to negotiate a services agreement. Significantly, these propositions are validated by the analyses undertaken in this paper.

\section{Related literature}

Research on services preferentialism has been traditionally devoted to studying the trade effect of services accords on aggregate and disaggregated services trade flows (Pak, 2002; Grünfeld and Moxnes, 2003; Ceglowski, 2006; Kimura and Lee, 2006; Walsh, 2006; Lennon, 2008; Shingal, 2009; Francois and Hoekman, 2010; Marchetti, 2011; Egger et al., 2012; Shingal, 2013; Van der Marel and Shepherd, 2013).

More recently, researchers have begun to explore the impact that differing levels of and heterogeneity in regulation exert on bilateral services trade flows (Kox and Lejour, 2006; Francois et al., 2007; Kox and Nordas, 2007; Schwellnus, 2007; Fink, 2009; Kox and Nordas, 2009; van der Marel and Shepherd, 2013) and to estimate barriers to trade in services and FDI and/or provide estimates of services trade costs (Francois et.al. 2007; Miroudot et al., 2010; Van der Marel, 2011; Miroudot et al., 2012).

This literature has also evolved to explain services commitments in the GATS (Roy, 2011), those made reciprocally (Marchetti et al., 2012) as well as GATS + commitments in STAs (Van der Marel and Miroudot, 2012).

However, the papers closest to ours are Baier and Bergstrand (2004), who were the first to 
examine the determinants of partners' propensities to negotiate trade agreements in goods, and Cole and Guillin (2012) and Egger and Wamser (2013), who explored the issue inter alia for services accords. None of these papers, however, examine the role of regulation in STA formation. Studying the role of regulation in STA membership is thus the main contribution of our paper. This is done through recourse to a new World Bank dataset on measures of services (regulatory) restrictiveness, the STRI (Borchert et al., 2012a,b).

Baier and Bergstrand (2004) found the potential welfare gains and likelihood of a PTA in goods trade between a pair of countries to be higher: (i) the closer in terms of distance two trading partners are; (ii) the more remote they are from the ROW; (iii) the larger and more similar they are economically (in terms of real GDPs) to enable exploitation of economies of scale in the presence of differentiated products; (iv) the greater is the difference in factor endowments between them, leading to Heckscher-Ohlin trade; and (v) the smaller is the difference in factor endowment ratios of the member countries relative to those of the ROW (leading to less inter-industry trade diversion). Baier and Bergstrand (2004) found these factors to have economically and statistically significant effects on the probability of negotiating a goods agreement.

In comparison, Cole and Guillin (2012) examined a dyad's propensity to negotiate a services agreement and in their baseline specification found statistically significant evidence only for the "natural trading partner hypothesis," similarity in terms of economic size, and factor

endowment differences. Egger and Wamser (2013) found the determinants of goods and services trade agreements to be similar.

\section{Empirical methodology}

Our empirical framework draws on McFadden $(1975,1976)$ qualitative choice models, where utility, here the (minimum or average) net gains for two countries from participating in an STA, is modeled as a latent, unobservable variable $(y *)$, which can be explained by a vector of explanatory variables $(x)$. Since $y *$ cannot be observed, an indicator variable $S T A$ is used which takes the value 1 (indicating $y *>0$ ) if two countries participate in a common STA and 0 (indicating $y * \leq 0$ ) otherwise.

More formally, $S T A_{i j}=1$ if $y *>0$ and $P\left(S T A_{i j}=1\right)=P(y *>0)=G\left(\alpha+\beta x_{i j}\right) \ldots \ldots(1)$

where $P$ is the response probability associated with a trading dyad $(i j)$ signing a services accord; $G($.$) is a cumulative distribution function that ensures that P\left(S T A_{i j}=1\right)$ lies in the unit interval; and $x_{i j}$ is the vector of explanatory variables for a generic country pair. 
Consistent with Baier and Bergstrand (2004), empirically, (1) is estimated by a probit model, assuming normality about the error term in the latent process. Clearly, independent of the assumed cumulative distribution function, the non-linear nature of $G($.$) implies that the$ coefficient estimates only reveal the signs of the partial effects of changes in $x_{i j}$ on the probability of signing a STA. Thus, the direction of the effect of variable $x_{k}$ on $E(y * \mid x)=$ $\alpha+\beta x$ is only qualitatively (not quantitatively) identical to the effect of $x_{k}$ on $E(S T A \mid x)=$ $G(\alpha+\beta x)$, where $E($.$) denotes the expectation operator.$

The main objective of STAs is to increase trade in services between partners. Reducing levels of restrictive regulation and promoting regulatory convergence are important channels through which services accords expand services trade volumes. Thus, the determinants of a country's choice to negotiate a services accord are likely to be indistinguishable from those that inform whether certain countries are more likely candidates for a reduction in restrictive regulation as well as for regulatory convergence.

Thus, in distinct regressions, we explain the restrictiveness of services regimes in a dyad and regulatory heterogeneity between partners using the same set of controls as used for explaining STA membership.

Formally, $D R E G_{i j}=\vartheta+\pi x+\varepsilon$

where $D R E G_{i j}$ is the absolute value of the difference between the logs of the services trade restrictiveness index $(S T R I)$ of two countries and $\varepsilon$ is an error term.

Moreover, $S R E G_{i j}^{l e v}=\mu+\varphi x+\zeta$

where $S R E G_{i j}^{l e v}$ is the sum of the levels of STRI of two countries and $\xi$ is an error term.

We found the dependent variables in equations (2) and (3) to be characterized by heteroskedasticity which rendered a log-linear OLS estimation biased (see Colin and Trivedi, 2005; Santos Silva and Tenreyro, 2006). Therefore we used Poisson pseudo-maximum likelihood (PPML) estimation for inference.

\section{Explanatory variables}

In their seminal work exploring the determinants of partners' propensities to negotiate bilateral trade agreements, Baier and Bergstrand (2004) documented that distance, remoteness, economic country size, and factor endowments were the main economic determinants of goods 
trade agreements and that their impact on empirical membership probability was consistent with economic theory. They also considered other institutional and political economy determinants in their sensitivity analyses. Following them, we use a largely overlapping set of determinants in our empirical analyses.

For any dyad $i j$, the vector $x$ includes two geographical variables: "Natural $i j$ " which is the inverse of distance between $i$ and $j$ and "Remote $i_{i j}$ " which is the simple average of the mean distance between both countries and their partners.

Formally, Remote $_{i j}=$ dcont $_{i j} \times\left\{\frac{\left[\log \left(\sum_{k=1, k \neq j}^{N} d_{i k /(N-1)}\right)+\log \left(\sum_{k=1, k \neq i}^{N} d_{j k /(N-1)}\right)\right]}{2}\right\}$

where " $d "$ is the bilateral distance in kilometers and "dcont $t_{i j}=1 "$ if $i$ and $j$ are located on the same continent, 0 otherwise.

Economic country sizes are represented by $S R G D P_{i j}$, which is the sum of the logs of real GDP of country $i$ and $j$ and $D R G D P_{i j}$, which is the absolute value of the difference between the logs of real GDP of two countries.

$D K L_{i j}$ and $D R O W K L_{i j}$ determine the role of factor endowments in countries' propensities to negotiate agreements. $D K L_{i j}$ is the absolute value of the difference between the $\operatorname{logs}$ of capital-labour ratios of country $i$ and $j$. Apart from $D K L_{i j}$, Baier and Bergstrand (2004) suggest using $S Q D K L_{i j}$ - the squared value of $D K L_{i j}$ - in order to control for the likely nonlinear impact of $D K L_{i j}$ on the net gains from participating in a trade agreement. Moreover, to account for dependence of $i$ and $j$ on each other, Baier and Bergstrand (2004) suggested including $D R O W K L_{i j}$ which is calculated as the absolute value of the difference between the logs of capital-labour ratios of countries $i$ and $j$ and those of ROW.

Formally, DROW $K L_{i j}=\frac{1}{2}\left[\left\{\log \left(\frac{\sum_{k=1, k \neq j}^{N} K_{k}}{\sum_{k=1, k \neq i}^{N} L_{k}}\right)-\log \left(\frac{K_{i}}{L_{i}}\right)\right\}+\left\{\log \left(\frac{\sum_{k=1, k \neq j}^{N} K_{k}}{\sum_{k=1, k \neq i}^{N} L_{k}}\right)-\log \left(\frac{K_{j}}{L_{j}}\right)\right\}\right]$

Institutional variables in $x_{i j}$ include common language, colonial antecedents and legal origins. More importantly from the perspective of this paper, we also control for the level of services regulation in the dyad $\left(S R E G_{i j}\right.$, which is the sum of the logs of $S T R I_{i}$ and $\left.S T R I_{j}\right)$ and regulatory heterogeneity between partners by including the absolute value of the difference between the logs of STRI of both countries $\left(D R E G_{i j}\right)$.

In line with the endogenous protection literature (Trefler, 1993), we also control for "import penetration" by using data on countries' average bilateral merchandise trade $\left(B T G_{i j}\right)$. To measure the average as well as the difference in the overall supply and demand potentials i.e. comparative advantage in and openness to overall services trade for two countries in the 
past, we also include the minimum value of world services trade for two countries in a dyad $\left[\min \left(\operatorname{Trade}_{i j}^{S}\right)\right]$ and the maximum value of world services trade for two countries in a dyad

$\left[\max \left(\operatorname{Trade}_{i j}^{S}\right)\right]$. Finally, to control for historical policy alignment, we also control for active goods trade agreements in the year 1980 (GTA_1980).

\section{$5 \quad$ Testable hypotheses}

The testable propositions from Baier and Bergstrand (2004) are likely to be similar for STAs as well. Thus:

1. Neighbouring countries are more likely to sign a trade agreement especially if both are remote from the rest of the world and this is likely to be true of services accords as well.

2. The "natural trading partner hypothesis" is also expected to hold true for STAs.

3. Similar and larger economically-sized countries are also likely to gain more due to the exploitation of economies of scale and the presence of greater varieties flowing from deeper integration in services markets.

4. The greater the difference in relative factor endowments between countries, and the larger the intercontinental trade costs, the more trade creation is likely to be.

5. The greater the difference in relative factor endowments between potential partners and the ROW, the more likely trade diversion becomes.

6. Protection tends to be higher in sectors with greater import penetration. This means that more bilateral trade is likely to be associated with a lesser inclination to negotiate a trade accord.

7. A small maximum inclination towards world services trade $\left[\max \left(\operatorname{Trade}_{i j}^{S}\right)\right]$ is likely to be associated with lesser inclination towards liberalization due to large natural services barriers. Moreover, given a small minimum inclination towards world services trade $\left[\min \left(\operatorname{Trade} e_{i j}^{S}\right)\right]$, a larger value of $\left[\max \left(\operatorname{Trade}_{i j}^{S}\right)\right]$ implies historically more heterogeneity between countries, which is expected to be a source of less inclination towards liberalizing services trade reciprocally.

8. Dyads with common institutions and homogeneity in regulation are more likely to enter into agreements as are partners with low initial barriers to services trade.

9. Partners with existing trade agreements in goods are also more likely to negotiate STAs. 
In estimating equation (1), we thus expect the coefficients of Remote $_{i j}$, Natural $_{i j}, S R G D P_{i j}$, $D K L_{i j}, S Q D K L_{i j}, G T A_{-} 1980, \min \left(\operatorname{Trade}_{i j}^{S}\right)$ and $\max \left(\operatorname{Trade}_{i j}^{S}\right)$, and the institutional variables to be positive while those of $D R G D P_{i j}, D R O W K L_{i j}, S R E G_{i j}, D R E G_{i j}$ and $B T G_{i j}$, to be negative.

\section{Data}

Data on trade agreements are taken from the WTO's Regional Trade Agreements Information System database, where $S T A=1$ for agreements notified under Article V of the GATS during 1958- 15 August 2013 and 0 otherwise. GT $A_{-} 1980=1$ for agreements notified under Article XXIV of the GATT during 1958-1980 and 0 otherwise.

The earliest STA was the EC Treaty that entered into effect (eif) in 1958 (but only notified to the WTO in 1995). After that, there was one STA in the 1980s (Australia-New Zealand, eif 1989), eight during the 1990s (including both the NAFTA and the EC enlargement) and 108 STAs since the year 2000 . Since trade agreements are typically phased in over a multiyear transition period, to control for potential endogeneity in estimation, our data on the time-varying independent variables in $x_{i j}$ are measured in the year 1980. The choice of this early year is also likely to control for any domino effects that the earliest STAs may have exerted on the recent wave of services preferentialism since 2000 during which 108 of the 118 WTO-notified STAs have come into effect.

The CEPII gravity dataset (Head et al., 2010) provides geographic distances between capital cities, used to compute Natural $_{i j}$ and Remote ${ }_{i j}$. Data on real GDP and population are taken from the Penn World Tables (Heston and Summers, 2011) and these are used to calculate $S R G D P_{i j}$ and $D R G D P_{i j}$.

We approximated factor endowment ratios $K_{i} / L_{i}$ by using real per capita income $(P C Y)$. This was done since we measured time-variant determinants of STAs 14 years prior to the data of STA membership (prior to the entering of all STAs in the data). At that time, using the perpetual inventory method to estimate capital stocks as in Baier and Bergstrand (2004) would have led to an unjustifiable loss of observations. Moreover, real per-capita income ratios are highly correlated with capital-labour ratios (see Egger and Larch, 2008; Bergstrand et al., 2010)2 ${ }^{2}$. Data on PCY are also taken from the Penn World Tables.

Data on common language and colonial antecedents are taken from the CEPII gravity dataset

\footnotetext{
${ }^{2}$ The correlation coefficient between real PCY and K/L in the subsample of our data for which both variables exist is close to 0.9 .
} 
(Head et al. 2010), while those on legal origins are compiled using La Porta et al. (1999) ${ }^{3}$. All trade data were averaged over 1979-1981 to minimize fluctuations in recording practices. Data on $B T G_{i j}$ were sourced from UN Comtrade. We used goods trade data as a measure of complementarity of bilateral goods and services trade, especially since bilateral services trade data are not available for a period as early as 1979-1981. $\min \left(\operatorname{Trade}_{i j}^{S}\right)$ and $\max \left(\operatorname{Trade}_{i j}^{S}\right)$ were calculated using data on world services trade from the World Bank's World Development Indicators.

Finally, ten countries in our sample did not exist in the year 1980: these included the Czech Republic and nine former USSR republics ${ }^{4}$. GDP and merchandise trade data for these countries were constructed for the year 1980 and $1980-82^{5}$, respectively. This was done by multiplying historical GDP and merchandise trade data (both corrected for inflation) for Czechoslovakia and the USSR by the shares of the Czech Republic and each of the nine former USSR republics, respectively, in "constructed Czechoslovakian" and "constructed USSR" GDP and merchandise trade in the year $1994^{6}$.

However, services trade data were not available historically and hence, these were constructed using actual data shares from $1999-2001^{7}$ as below:

$\operatorname{Trade}_{i 1979-81}^{S}=\sum_{i} \operatorname{Trade}_{i 1979-81}^{S} \times \frac{\text { Trade }_{i 1999-2001}^{S}}{\sum_{i} \operatorname{Trade}_{i 1999-2001}^{S}}$

The measure of regulation in services markets used in this paper is the World Bank's Services Trade Restrictiveness Index (STRI; Borchert et.al. 2012 a, b). Compiled from responses to questionnaires sent out by the World Bank to 79 developing countries on "impediments to international integration" and from publicly available information for OECD countries, the STRI is a quantitative index of restrictions on services trade encompassing 103 countries, 5 major service sectors and 19 sub-sectors. The information is also available by modes of service delivery.

A comparison of STRI by regions/groups in Figure 1 shows that the Middle-East \& North Africa (MENA) has the most restrictive services trade policies, followed by South Asia (SA), East Asia \& the Pacific (EAP) and Sub-Saharan Africa (SSA), with the last also being the most heterogeneous cohort. As expected, the OECD and East \& Central Asia (ECA) not only report the lowest STRI values but also form the most homogeneous cohorts.

\footnotetext{
${ }^{3}$ http://www.economics.harvard.edu/faculty/shleifer/files/qgov_web.xls

${ }^{4}$ These were Armenia, Belarus, Georgia, Kazakhstan, the Kyrgyz Republic, Lithuania, Russia, Ukraine and Uzbekistan.

${ }^{5}$ Trade data for these countries were missing in 1979.

${ }^{6}$ This was the earliest year of the coming into existence of all these ten countries.

${ }^{7}$ These were the earliest years for which services trade data were consistently available for all these ten countries.
} 


\section{$<$ Insert Figure 1 here $>$}

A closer look at Figure 1 also provides an insight into the factors likely to influence the choice of partners for negotiated regulatory convergence. For instance, high levels of per capita income (PCY), economic development and political stability all likely feature behind the observed homogeneity in STRI among OECD countries though there are significant differences in language, culture and distances within this cohort. In the case of ECA on the other hand, there is far more homogeneity in terms of language, culture and distances, though more differences in terms of PCY and levels of development. This seems to suggest that a combination of these factors could determine which countries are potential candidates for negotiated regulatory convergence.

The STRI data are available for 103 countries, leading to $5253[=(103 \times 102) / 2]$ possible dyads (treating pair $i j$ and pair $j i$ as the same dyad). There was an STA in force between 462 of these dyads until 15 August 2013. A preliminary analysis of the variables in $x_{i j}$ shown in Figure 2 reveals that STA members relative to non-members in our sample are closer in terms of distance but more remote, larger in terms of real GDP and more similarly-sized, have smaller differences in PCY (and hence, relative factor endowments) with respect to each

other but not compared to ROW, display less restrictive and more homogeneous services regulation, are more likely to have a common language, and exhibit higher (historical) levels of bilateral merchandise trade. The 103 countries in our sample are listed in Annex Table A1 and all data are summarized in Annex Table A2.

\section{$<$ Insert Figure 2 here $>$}

\section{Estimation results}

The results from the Probit estimation are reported in Table 1. The first three specifications control for economic and trade determinants first separately and then together. Specification 4 introduces institutional controls while specifications 5 and 6 include combinations of these with economic and trade determinants. The final specification 7 controls for all determinants together.

\section{$<$ Insert Table 1 here $>$}

The results reported in columns 1,2 and 4 suggest that economic determinants exert a greater influence than both institutional and trade factors though the model has the lowest 
explanatory power with the lattermost (pseudo-R-squared $=12 \%$ ). Moreover, most of the variables within these three sets of determinants, with the exception of the factor-endowment proxies and common law, are individually statistically significant.

As expected, less distant and more remote dyads, large sized economies with less restrictive and more homogeneous services regulation and a common language are more likely to negotiate a services accord. The coefficients on $D P C Y$ and $D R O W P C Y$ provide no evidence in these results for either Hecksher-Ohlin trade determinants in driving STAs or for any interindustry trade diversion. Counter-intuitively, these results also suggest that having common colonial antecedents reduces the propensity to negotiate a STA. The unexpected positive coefficient on $B T G_{i j}$ seems to provide more evidence in support of the domino theory (Baldwin, 2006) than for the endogenous protection literature. While the GTA_1980 variable drops out of these estimations, the positive coefficients on $\min \left(\operatorname{Trade}_{i j}^{S}\right)$ and $\max \left(\operatorname{Trade}_{i j}^{S}\right)$ provide evidence for both supply and demand factors in fostering reciprocal services liberalization.

These results generally hold in specifications 3,5 and 6 though the explanatory power of the model is considerably improved when economic and institutional factors are combined. When all factors are controlled for in specification 7, only $\operatorname{Remote}_{i j}$, Natural $_{i j}, D R G D P_{i j}$, services trade and the regulatory variables retain statistical significance; these variables have the same impact as earlier. Interestingly, the explanatory power of this fully specified model is the same as that of the model with economic and institutional determinants being combined together; since the latter covers the full sample, we use it to assess our model's predictive power.

A comparison ${ }^{8}$ of our model's predictions for STA using the specification in column 5 with the actual value of STA reveals that the propensity to negotiate (or not) a STA is correctly predicted for $93 \%$ of the dyads in our sample. Of the total, there was an STA between 462 dyads and $39.4 \%$ of these were correctly predicted by the model. The remaining 4791 dyads did not have a services accord and our model correctly predicted $98.3 \%$ of these. Matthews (1975) correlation coefficient $^{9}$, calculated from these predictions, reported a value of 0.49 , indicating reasonable fit between the actual and predicted propensities to negotiate STAs.

We also found evidence of "insufficient" services preferentialism in our sample for 83 possible trading partner pairs reported in Table 2 wherein our model suggested the existence of a services accord which does not exist at the moment. At the same time, 280 dyads reported

\footnotetext{
${ }^{8}$ To enable this comparison, we used the standard decision-rule for assessing probit models. If $S T A^{\text {pred }}>$ 0.5 then we take this value to be 1 . If $S T A^{\text {pred }}<=0$ then we take this value to be 0 .

${ }^{9} M C C=((T P \times T N)-(F P \times F N)) / \sqrt{(T P+F P) \times(T P+F N) \times(T N+F P) \times(T N+F N)}$ where $\mathrm{MCC}=$ Matthews correlation coefficient, $\mathrm{TP}=$ number of true positives, $\mathrm{TN}=$ number of true negatives, $\mathrm{FP}=$ number of false positives and $\mathrm{FN}=$ number of false negatives.
} 
in Table 3 seem to exhibit "excessive" services preferentialism - in all cases, both sets of trading partners have a services agreement though our model suggests a very low probability for this.

\section{$<$ Insert Tables $2 \& 3$ here $>$}

\subsection{Secondary results}

Table 4 reports the results from the PPML estimation of equation (2). As before, columns 1, 2 and 4 report the results from estimations that control for economic, trade and institutional determinants separately; columns 3,5,6 and 7 report results from estimations that include these variables in different combinations.

\section{$<$ Insert Table 4 here $>$}

At the outset, the explanatory power of the secondary estimation is low; even the fullyspecified model in column 7 has an R-squared of only $5.9 \%$. This said, a few of the explanatory variables report expected signs on coefficients. Thus, dyads more remote from ROW tend to be more homogeneous in services regulation - the coefficient on Remote $_{i j}$ is negative and statistically significant across specifications. Commonality in institutions is likely to result in a demand for (and greater supply of) regulatory convergence - we see evidence of this in the coefficients on common colonial antecedents and common language in specifications 4 through 7 .

On the other hand, $D R G D P_{i j}$ reports statistical significance, but unexpected signs. The result on the sum of economic size of trading partners is harder to interpret as our sample data suggest the near-absence of a relationship between market size and regulatory heterogeneity (correlation coefficient $=-0.05)$. The impact of combined market size on differences in regulation is thus uncertain and perhaps this is what is reflected in the near-zero coefficient on $S R G D P_{i j}$ across specifications in Table 4.

The coefficient on $B T G_{i j}$ is negative as expected and statistically significant throughout specifications. Sectors characterized by greater trade intensity are also more likely to see a convergence in regulation facilitating such trade. Finally, the positive coefficients on $\min \left(\operatorname{Trade}_{i j}^{S}\right)$ are also in line with our expectations on historical regulatory heterogeneity.

While there are no established a priori for explaining the restrictiveness of services regimes in a dyad, results from the PPML estimation of equation (3) reported in Table 5 suggest more restrictive services regimes in a dyad if: 
- it is more remote from ROW;

- the countries in the dyad are more distant from each other;

- it comprises smaller sized and dissimilar economies;

- it has larger differences in factor endowments both between members and compared to ROW;

- it has lower levels of pre-existing bilateral merchandise trade or the absence of any institutionalized preferential trading arrangement in goods;

- there are differences in language (though weakly significant) between the members;

- if there is more minimum inclination towards world services trade and less maximum inclination; and

- interestingly, if it has common legal and colonial antecedents

\section{$<$ Insert Table 5 here $>$}

\subsection{Sensitivity analysis}

The STRI data generally pertain to the year 2008 for most countries in the sample. Since regulatory convergence and a reduction in services restrictiveness are objectives of services preferentialism, to minimize endogeneity in our estimation emanating from reverse causality, we now only consider services accords that came into effect in the year 2008 and beyond. Results from estimating equations (1) to (3) for this sub-sample are reported in Annex Tables 3 to 5 , respectively.

These robustness results from equation (1) provide little evidence for the role of factorendowments or for common colonial antecedents in determining STA membership. On the other hand, these results provide more robust evidence for the positive role of a common language and counter-intuitive evidence for the negative impact of the common law variable. The coefficient on the $\min \left(\operatorname{Trade}_{i j}^{S}\right)$ variable also turns negative in specifications 2 and 3 , thus negating the role of supply forces in promoting services preferentialism. The remaining results in Annex Table 3 are qualitatively similar to those reported in Table 1: the impact of Remote $_{i j}, S R G D P_{i j}$ and the regulatory variables is lesser than in the full sample and there is more robust evidence for the positive role of the $B T G_{i j}$ variable.

Annex Tables 4 and 5 report the robustness results from estimating equations (2) and (3) and these are found to be qualitatively similar in general to those reported in Tables 4 and 5, respectively, though the GTA_1980 drops out of these results. 
In Annex Table 4 results, the coefficient on Natural $_{i j}$ is statistically significant while those on $S R G D P_{i j}$ and $D R O W P C Y_{i j}$ are weakly significant; the common language variable reports a more robust presence in these results. However, the likely impacts of all these variables on regulatory heterogeneity in a dyad are the same as in the full sample.

In Annex Table 5 results, the one major difference is the change in the sign of the Natural $_{i j}$ variable: the robustness results suggest that the restrictiveness of services regulation in the dyad is inversely related to the geographical distance between the countries, which is a rather interesting result. The impact of factor endowment differences also acquires a nonlinear relationship now. The remaining variables retain impacts similar to those in the full sample.

\section{Conclusion}

This paper examines the role of regulatory incidence and convergence in determining STA membership. Our empirical results suggest that large-and similar-sized economies that are distance-wise closer and remote (from ROW), with lower levels of restrictive but more homogeneous services regulation are more likely to negotiate services agreements with each other. Our results also suggest that remote and less similar-sized economies, with high levels of bilateral merchandise trade, common language and colonial antecedents are more likely candidates for regulatory convergence in STAs. Finally, the restrictiveness of services regimes in a dyad seems to be directly related to its remoteness from ROW, to the geographical distance between the countries and to their factor endowment differences as well as interestingly to commonality in legal institutions and colonial antecedents. The incidence of services regulation in a dyad is also found to be inversely related to the sizes of and similarities between countries in terms of GDP, to levels of bilateral merchandise trade and pre-existing goods agreements. Our results suggest that regulation (both incidence and heterogeneity) are important determinants of STAs. They also suggest that geography, common institutions and pre-existing trade matter more than economic size and factor endowments for addressing regulatory incidence and convergence in services negotiations. Finally, we also find that countries displaying greater regulatory convergence and less restrictive regulation are more likely candidates for reciprocal services liberalization. 


\section{References}

Anderson, J. E. and van Wincoop, E. (2003). Gravity with gravitas: a solution to the border puzzle. American Economic Review, 93(1):170-192.

Anderson, J. E. and van Wincoop, E. (2004). Trade costs. Journal of Economic Literature, 42:691-751.

Baier, S. L. and Bergstrand, J. H. (2004). Economic determinants of free trade agreements. Journal of International Economics, 64(1):29-63.

Baier, S. L. and Bergstrand, J. H. (2007). Do free trade agreements actually increase members' international trade? Journal of international Economics, 71(1):72-95.

Baier, S. L. and Bergstrand, J. H. (2009). Bonus vetus ols: A simple method for approximating international trade-cost effects using the gravity equation. Journal of International Economics, 77(1):77-85.

Baldwin, R. (2006). Multilateralising regionalism: spaghetti bowls as building blocs on the path to global free trade. The World Economy, 29(11):1451-1518.

Bergstrand, J., Egger, P., and Larch, M. (2010). Economic determinants of the timing of preferential trade agreement formations and enlargements. Notre Dame, University of Notre Dame, Working Paper.

Bergstrand, J., Egger, P., and Larch, M. (2013). Gravity redux: Estimation of gravityequation coefficients, elasticities of substitution, and general equilibrium comparative statics under asymmetric bilateral trade costs. Journal of International Economics, 89(1):110121.

Borchert, I., Gootiiz, B., and Mattoo, A. (2012a). Guide to the services trade restrictions database. World Bank Policy Research Working Paper, (6108).

Borchert, I., Gootiiz, B., and Mattoo, A. (2012b). Policy barriers to international trade in services: evidence from a new database. World Bank Policy Research Working Paper, (6109).

Ceglowski, J. (2006). Does gravity matter in a service economy? Review of World Economics, $142(2): 307-329$.

Cole, M. and Guillin, A. (2012). The determinants of trade agreements in services vs goods. 
Colin, C. A. and Trivedi, P. K. (2005). Microeconometrics: Methods and applications.

Eaton, J. and Kortum, S. (2002). Technology, geography, and trade. Econometrica, 70(5):1741-1779.

Egger, P. and Larch, M. (2008). Interdependent preferential trade agreement memberships: An empirical analysis. Journal of International Economics, 76(2):384-399.

Egger, P., Larch, M., and Staub, K. E. (2012). Trade preferences and bilateral trade in goods and services: A structural approach. Technical report, CEPR Discussion Papers.

Egger, P., Larch, M., Staub, K. E., and Winkelmann, R. (2011). The trade effects of endogenous preferential trade agreements. American Economic Journal: Economic Policy, $3(3): 113-143$.

Egger, P. and Wamser, G. (2013). Effects of the endogenous scope of preferentialism on international goods trade. Technical report, CESifo Working Paper.

Fink, C. (2009). Has the eu's single market program led to deeper integration of eu services markets? GEM Working paper.

Francois, J. and Hoekman, B. (2010). Services trade and policy. Journal of Economic Literature, pages 642-692.

Francois, J., Hoekman, B., and Woerz, J. (2007). Does gravity apply to intangibles? measuring barriers to trade in services. In Recent Developments in International Trade in Services.

Grünfeld, L. A. and Moxnes, A. (2003). The intangible globalization: Explaining the patterns of international trade in services. Norwegian Institute for International Affairs. Working Paper, (657-2003).

Head, K., Mayer, T., and Ries, J. (2010). The erosion of colonial trade linkages after independence. Journal of International Economics, 81(1):1-14.

Heston, A. and Summers, R. (2011). B. aten (2011), penn world table version 7.0. Center for International Comparisons of Production, Income and Prices, University of Pennsylvania.

Hoekman, B. and Kostecki, M. (2001). The Political Economy of the World Trading System: WTO and Beyond. Oxford University Press.

Kimura, F. and Lee, H. (2006). The gravity equation in international trade in services. Review of world economics, 142(1):92-121. 
Kox, H. and Lejour, A. (2006). The effects of the services directive on intra-eu trade and fdi. Revue Economique, 57(4):747-769.

Kox, H. and Nordås, H. (2007). Services trade and domestic regulation.

Kox, H. and Nordas, H. (2009). Regulatory harmonization and trade in services: Volumes and choice of mode.

La Porta, R., Lopez-de Silanes, F., Shleifer, A., and Vishny, R. (1999). The quality of government. Journal of Law, Economics, and Organization, 15(1):222-279.

Lennon, C. (2008). Trade in services and trade in goods: Differences and complementarities. WIIW Working Papers 53.

Magdeleine, J. and Maurer, A. (2008). Measuring gats mode 4 trade flows. Available at SSRN 1291090.

Marchetti, J. (2011). Do economic integration agreements lead to deeper integration of services markets? International Handbook on the Economics of Integration: Factor, Mobility, Agriculture, Environment and Quantitative Studies, 3:435.

Marchetti, J., Roy, M., and Zoratto, L. (2012). Is there reciprocity in preferential trade agreements on services? Technical report, Staff Working Paper ERSD.

Matthews, B. (1975). Comparison of the predicted and observed secondary structure of t4 phage lysozyme. Biochimica et Biophysica Acta (BBA)-Protein Structure, 405(2):442-451.

Mattoo, A. and Sauvé, P. (2010). The preferential liberalization of services trade. Swiss National Centre of Competence in Research (NCCR) Working Paper, (2010/13).

McFadden, D. (1975). The revealed preferences of a government bureaucracy: Theory. The Bell Journal of Economics, pages 401-416.

McFadden, D. (1976). Quantal choice analaysis: A survey. In Annals of Economic and Social Measurement, Volume 5, number 4, pages 363-390. NBER.

Miroudot, S., Sauvage, J., and Shepherd, B. (2010). Measuring the cost of international trade in services. GEM Working paper.

Miroudot, S., Sauvage, J., and Shepherd, B. (2012). Trade costs and productivity in services sectors. Economics Letters, 114(1):36-38. 
Pak, S. (2002). How far has regional integration deepened?: evidence from trade in services, volume 2. Korea Institute for International Economic Policy.

Roy, M. (2011). Democracy and the political economy of multilateral commitments on trade in services. Journal of World Trade, 45(6):1157-1180.

Santos Silva, J. and Tenreyro, S. (2006). The log of gravity. The Review of Economics and Statistics, 88(4):641-658.

Sauvé, P. and Shingal, A. (2011). Reflections on the preferential liberalization of services trade. Journal of World Trade, 45(5):953.

Schwellnus, C. (2007). The effect of domestic regulation on services trade revisited. Technical report.

Shingal, A. (2009). How much do agreements matter for services trade? MPRA paper 32815.

Shingal, A. (2013). Revisiting the trade effects of services agreements. MPRA paper 52143.

Trefler, D. (1993). Trade liberalization and the theory of endogenous protection: an econometric study of us import policy. Journal of Political Economy, pages 138-160.

Van der Marel, E. (2011). Determinants of comparative advantage in services.

Van der Marel, E. and Miroudot, S. (2012). The economics and political economy of going beyond the gats. London School of Economics, mimeo.

Van der Marel, E. and Shepherd, B. (2013). Services trade, regulation and regional integration: Evidence from sectoral data. The World Economy.

Walsh, K. (2006). Trade in services: Does gravity hold? a gravity model approach to estimating barriers to services trade. Technical report, IIIS. 
Figure 1: Comparison of STRI across regions/groups

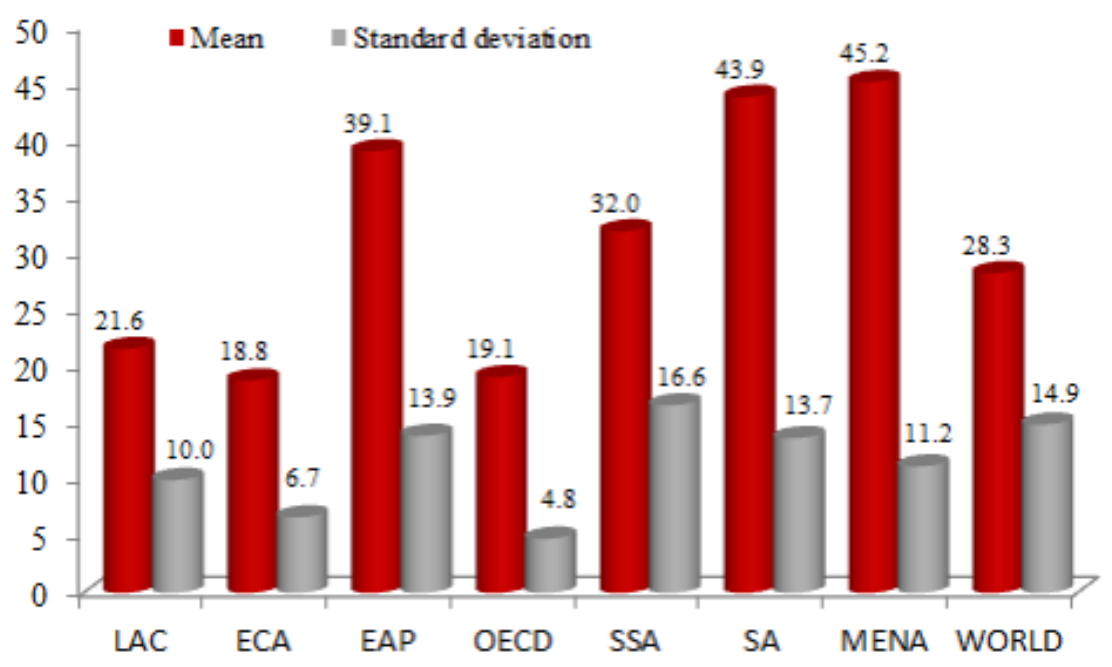

Source: Author calculations based on World Bank STRI database

Figure 2: Role of STA determinants: Members v Outsiders (ratio of mean values)

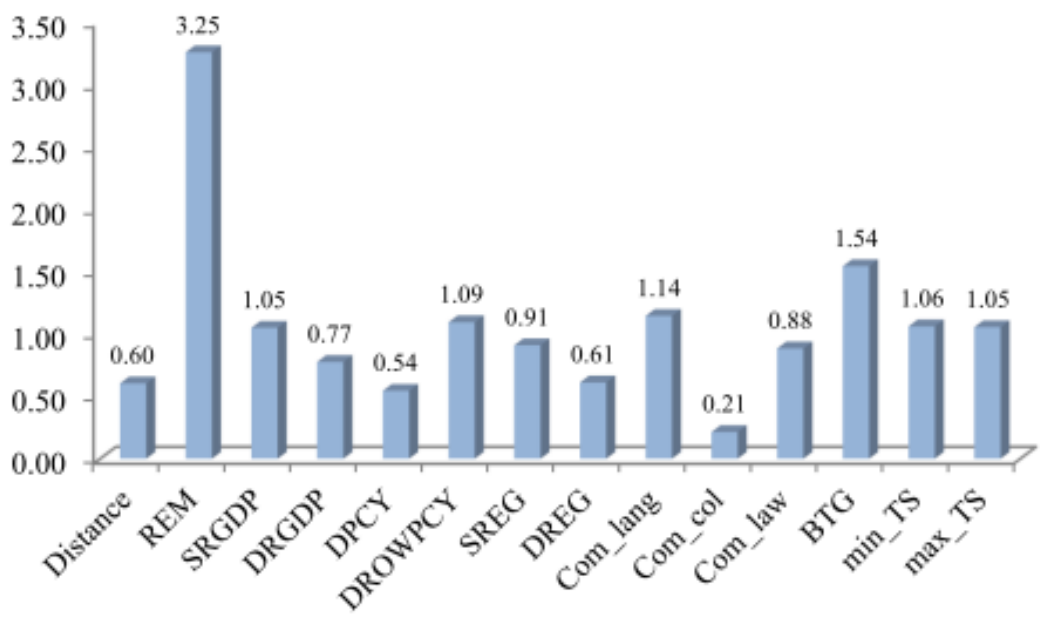


Table 1: Estimating the likelihood of negotiating a services trade agreement

\begin{tabular}{|c|c|c|c|c|c|c|c|}
\hline \multicolumn{8}{|c|}{ Probit estimation: Dependent variable STA } \\
\hline & (1) & (2) & (3) & (4) & (5) & (6) & (7) \\
\hline Remote $(+)$ & $\begin{array}{c}0.065^{* * *} \\
(0.009)\end{array}$ & & $\begin{array}{c}0.067^{* * *} \\
(0.010)\end{array}$ & & $\begin{array}{c}0.081^{* * *} \\
(0.011)\end{array}$ & & $\begin{array}{c}0.088^{* * * *} \\
(0.011)\end{array}$ \\
\hline Natural $(+)$ & $\begin{array}{c}0.286^{* * *} \\
(0.044)\end{array}$ & & $\begin{array}{c}0.255^{* * *} \\
(0.047)\end{array}$ & & $\begin{array}{c}0.248^{* * *} \\
(0.051)\end{array}$ & & $\begin{array}{c}0.236^{* * *} \\
(0.054)\end{array}$ \\
\hline SRGDP $(+)$ & $\begin{array}{c}0.205^{* * *} \\
(0.012)\end{array}$ & & $\begin{array}{c}0.080^{* * *} \\
(0.024)\end{array}$ & & $\begin{array}{c}0.188^{* * *} \\
(0.014)\end{array}$ & & $\begin{array}{c}0.025 \\
(0.028)\end{array}$ \\
\hline DRGDP (-) & $\begin{array}{c}-0.092 * * * \\
(0.023)\end{array}$ & & $\begin{array}{c}-0.172^{* * * *} \\
(0.030)\end{array}$ & & $\begin{array}{c}-0.128^{* * *} \\
(0.025)\end{array}$ & & $\begin{array}{c}-0.126^{* * * *} \\
(0.034)\end{array}$ \\
\hline $\mathrm{DPCY}(+)$ & $\begin{array}{l}-0.038 \\
(0.111)\end{array}$ & & $\begin{array}{l}-0.154 \\
(0.114)\end{array}$ & & $\begin{array}{c}0.028 \\
(0.119)\end{array}$ & & $\begin{array}{l}-0.049 \\
(0.124)\end{array}$ \\
\hline SQDPCY $(+)$ & $\begin{array}{l}-0.083^{*} \\
(0.038)\end{array}$ & & $\begin{array}{l}-0.057 \\
(0.038)\end{array}$ & & $\begin{array}{l}-0.061 \\
(0.039)\end{array}$ & & $\begin{array}{l}-0.041 \\
(0.040)\end{array}$ \\
\hline DROWPCY (-) & $\begin{array}{c}0.088 \\
(0.067)\end{array}$ & & $\begin{array}{l}-0.068 \\
(0.074)\end{array}$ & & $\begin{array}{l}0.211^{* *} \\
(0.080)\end{array}$ & & $\begin{array}{l}-0.025 \\
(0.087)\end{array}$ \\
\hline BTG (-) & & $\begin{array}{c}0.058^{* * *} \\
(0.006)\end{array}$ & $\begin{array}{c}0.020^{* *} \\
(0.007)\end{array}$ & & & $\begin{array}{c}0.059^{* * * *} \\
(0.008)\end{array}$ & $\begin{array}{l}0.019^{*} \\
(0.008)\end{array}$ \\
\hline $\min \left(\operatorname{Trade}^{\mathrm{S}}\right)(+)$ & & $\begin{array}{c}0.117^{* * * *} \\
(0.022)\end{array}$ & $\begin{array}{l}-0.030 \\
(0.033)\end{array}$ & & & $\begin{array}{c}0.205^{* * *} \\
(0.024)\end{array}$ & $\begin{array}{c}0.141^{* * *} \\
(0.038)\end{array}$ \\
\hline $\max \left(\operatorname{Trade}^{\mathrm{S}}\right)(+)$ & & $\begin{array}{l}0.052^{*} \\
(0.024)\end{array}$ & $\begin{array}{c}0.246^{* * *} \\
(0.043)\end{array}$ & & & $\begin{array}{l}-0.012 \\
(0.027)\end{array}$ & $\begin{array}{c}0.179^{* * *} \\
(0.048)\end{array}$ \\
\hline SREG (-) & & & & $\begin{array}{c}-0.640^{* * * *} \\
(0.043)\end{array}$ & $\begin{array}{c}-0.707^{* * * *} \\
(0.051)\end{array}$ & $\begin{array}{c}-0.769^{* * * *} \\
(0.050)\end{array}$ & $\begin{array}{c}-0.747^{* * * *} \\
(0.055)\end{array}$ \\
\hline DREG (-) & & & & $\begin{array}{c}-0.766^{* * * *} \\
(0.080)\end{array}$ & $\begin{array}{c}-0.551^{* * * *} \\
(0.094)\end{array}$ & $\begin{array}{c}-0.755^{* * * *} \\
(0.090)\end{array}$ & $\begin{array}{c}-0.561^{* * * *} \\
(0.096)\end{array}$ \\
\hline Com_lang $(+)$ & & & & $\begin{array}{l}0.218^{* * *} \\
(0.080)\end{array}$ & $\begin{array}{l}0.199^{*} \\
(0.094)\end{array}$ & $\begin{array}{c}0.083 \\
(0.088)\end{array}$ & $\begin{array}{c}0.017 \\
(0.098)\end{array}$ \\
\hline Com_col $(+)$ & & & & $\begin{array}{c}-0.514^{* * *} \\
(0.180)\end{array}$ & $\begin{array}{l}-0.496^{*} \\
(0.212)\end{array}$ & $\begin{array}{l}-0.071 \\
(0.198)\end{array}$ & $\begin{array}{l}-0.342 \\
(0.220)\end{array}$ \\
\hline Com_law $(+)$ & & & & $\begin{array}{l}-0.057 \\
(0.062)\end{array}$ & $\begin{array}{l}-0.062 \\
(0.077)\end{array}$ & $\begin{array}{l}-0.023 \\
(0.071)\end{array}$ & $\begin{array}{l}-0.023 \\
(0.079)\end{array}$ \\
\hline Constant & $\begin{array}{c}-9.079^{* * * *} \\
(0.721)\end{array}$ & $\begin{array}{c}-5.626^{* * * *} \\
(0.568)\end{array}$ & $\begin{array}{c}-7.780^{* * * * *} \\
(0.819)\end{array}$ & $\begin{array}{c}2.995^{* * * *} \\
(0.260)\end{array}$ & $\begin{array}{c}-4.111^{\text {***** }} \\
(0.844)\end{array}$ & $\begin{array}{l}-0.891 \\
(0.685)\end{array}$ & $\begin{array}{c}-2.544 * * \\
(0.971)\end{array}$ \\
\hline $\mathbf{N}$ & 5253 & 4786 & 4786 & 5253 & 5253 & 4786 & 4786 \\
\hline df_m & 7 & 3 & 10 & 5 & 12 & 8 & 15 \\
\hline Pseudo-r2 & 0.286 & 0.12 & 0.287 & 0.144 & 0.384 & 0.264 & 0.385 \\
\hline
\end{tabular}

Note: Levels of significance: $\# 10 \% * 5 \% * * 1 \% * * * 0.1 \%$; standard errors reported in brackets. The signs against the variables denote the expected signs of the coefficients. 
Table 2: Dyads exhibiting "insufficient" preferentialism $(\mathrm{n}=83)$

\begin{abstract}
ARG-CHL .5452351 ARG-COL .6323817 ARG-PER .6694701 ARG-USA .5557622 ARM-GEO .6910012 ARM-POL .5317407 AUT-RUS .670308 AUT-TUR .5768433 AUT-UKR .595938 AUT-USA .5079905 BEL-RUS .6535662 BEL-TUR .5125991 BEL-UKR .5541996 BGR-TUR .5685432 BLR-RUS .5015196 BOL-PER .5460728 BRA-USA .5102936 CAN-DEU .5212128 CAN-GBR .5664355 COL-PER .6476514 CZE-RUS .5034283 DEU-JPN .5559747 DEU-RUS .8723326 DEU-TUR .6277232 DEU-UKR .6881992 DEU-USA .7916232 DNK-RUS.6142139 DNK-UKR .5090121 DOM-TTO.6399667 ECU-PER .6847796 ESP-TUR .5526477 ESP-UKR .6111115 ESP-USA .7369705 FIN-RUS .6289294 FRA-RUS .8102681 FRA-TUR .5349486 FRA-UKR .6362016 FRA-USA .5770085 GBR-USA .7787322 GEO-LTU .5158181 GEO-NLD .5424612 GEO-POL .6056658 GEO-ROU .5017859 GRC-RUS.6256635 GRC-TUR .6255006 GRC-UKR .5523894 HUN-RUS .5850164 HUN-TUR .551712 HUN-UKR .5334193 ITA-RUS .7959356 ITA-TUR .572157 ITA-UKR .6492805 ITA-USA .535962 JPN-GBR .5003162 JPNKAZ .5673377 JPN-KOR .6720359 JPN-RUS.5476456 JPN-USA .6517093 LTU-RUS.5540285 NLD-RUS.746981 NLD-TUR .5729212 NLD-UKR .652862 NLD-USA .6366677 POL-RUS .7364851 POL-TUR .6401028 POL-UKR .6904365 POL-USA .5594306 ROU-RUS .6112943 ROU-TUR .6688879 ROU-UKR .5799432 RUS-ESP .7384313 RUS-GBR .8147359 RUS-SWE .7117395 RUS-TUR .6154693 RUS-UKR .7139575 RUS-USA .6218069 SWE-TUR .5414885 SWE-UKR .5944301 SWE-USA .5331776 TTO-USA .6760481 TUR-GBR .6056189 TUR-UKR .5758041 UKR-GBR .6583456
\end{abstract}

Note: The figures are the associated estimated probabilities of negotiating an STA from the Probit estimation in Column 5 (Table 2) 
Table 3: Dyads exhibiting "excessive" preferentialism $(\mathrm{n}=280)$

ALB-AUT .3394816 ALB-BEL .2227186 ALB-BGR .3834628 ALB-CZE .2909101 ALB-DEU .3373346 ALB-DNK .2337435 ALB-ESP .3022056 ALB-FIN .1503235 ALB-FRA .1943843 ALB-GBR .3213648 ALB-GRC .3900247 ALB-HUN .3377046 $A L B-I R L .253518$ ALB-ITA .2592226 ALB-LTU .2652707 ALB-NLD .3097778 ALB-POL .3329031 ALB-PRT .2006759 ALB-ROU .3617223 ALB-SWE .2710089 ARG-PRY .4960309 ARG-VEN .3527648 AUS-CHL .0891603 AUS-IDN .0305792 AUS-KHM .0052218 AUS-MYS .0153956 AUS-PHL .0276533 AUS-THA .0171398 AUS-USA .4943056 AUS-VNM .00558 AUT-CHL .0821173 AUT-COL .2285361 AUT-DOM .1213886 AUT-KOR .1693152 AUT-MEX .152108 AUT-PER .2037986 AUT-TTO .1763631 BDI-KEN .0997498 BDI-RWA .1412126 BDI-TZA .0878041 BDI-UGA .0917294 BEL-BGR .4472129 BEL-CHL .0717858 BEL-COL .1508995 BEL-DOM .0692336 BEL-KOR .1874139 BEL-MEX .1497269 BEL-PER .1245611 BEL-TTO.1171765 BGR-CHL .0610479 BGR-COL .1288048 BGR-DNK .4699221 BGR-DOM .1307498 BGR-FIN .3539574 BGR-FRA .410113 BGR-ITA .4649507 BGR-KOR .0900754 BGR-MEX .0575929 BGR-PER .1486043 BGR-PRT .3996082 BGR-TTO.1429612 BHR-USA .0096414 BRA-PRY .3027615 BRA-URY .2527725 BRA-VEN .2984049 CAN-CHL .1049485 CAN-COL .2475127 CAN-PAN .0409915 CAN-PER .1981352 CHL-CHN .0158337 CHL-COL .3742454 CHL-CRI .0383564 CHL-CZE .073893 CHL-DEU .1106026 CHL-DNK.0744666 CHL-ESP.1331781 CHL-FIN .0551355 CHL-FRA .0668133 CHL-GBR .1111771 CHL-GRC .0733949 CHL-GTM .0980022 CHL-HND .0417879 CHL-HUN .0796652 CHL-IRL .0805019 CHL-ITA .0627481 CHL-JPN .0916949 CHL-KOR .0575875 CHL-LTU .0692718 CHL-MEX .0900848 CHL-NIC .042904 CHL-NLD .0893551 CHL-NZL .0972232 CHL-PAN .0043473 CHL-PER .4291661 CHL-POL .0974287 CHL-PRT .0725759 CHL-ROU .0813705 CHL-SWE .0842959 CHL-USA .2097511 CHN-CRI .0057676 CHN-IDN .2200616 CHN-MYS .1264379 CHN-NZL .0157077 CHN-PAK .3074328 CHN-PER .0283177 CHN-PHL .1518293 CHN-THA .1694371 CHN-VNM .1874146 COL-CZE .3405844 COL-DEU .2807534 COL-DNK .165942 COL-ESP .3234821 COL-FIN .096252 COL-FRA .1327514 COL-GBR .288097 COL-GRC .2058247 COL-GTM .2508087 COL-HND .1092298 COL-HUN .2165056 COL-IRL .1698878 COL-ITA .1227859 COL-LTU .1463802 COL-MEX .2008591 COL-NLD .2464357 COL-POL .2583369 COL-PRT .1502477 COL-ROU .2235911 COL-SWE .2362178 COL-USA .4829012 CRI-DOM .2301657 CRI-MEX .2781849 CRI-PAN .0854918 CRI-PER .0657363 CRI-USA .3621816 CZE-DOM .1300981 CZE-FIN .4759774 CZE-KOR .1227521 CZE-MEX .0864925 CZE-PER .1943287 CZE-PRT .4956925 CZE-TTO.1506371 DEU-KOR .2225434 DEU-MEX .3126218 DEU-PER .2621549 DEU-TTO .230544 DNK-DOM .0825411 DNK-KOR .1477791 DNK-MEX .1194977 DNK-PER .1452506 DNK-TTO.1221288 DOM-DEU .1666548 DOM-ESP .2235879 DOM-FIN .0481801 DOM-FRA .0591344 DOM-GBR .232862 DOM-GRC.1039282 DOM-GTM .4697232 DOM-HND .2851547 DOM-HUN .1233463 DOM-IRL .2364771 DOM-ITA .0531452 DOM-LTU .2087243 DOM-NIC .4952163 DOM-NLD .2424529 DOM-POL .2581225 DOM-PRT .0767349 DOM-ROU .1728355 DOMSWE .1616863 ESP-TTO .2404292 FIN-GRC .489732 FIN-IRL .4383807 FIN-KOR .1116898 FIN-MEX .0997606 FINPER .0911799 FIN-PRT .4196983 FIN-ROU .4871558 FIN-TTO .0719794 FRA-KOR .1707282 FRA-LTU .4870101 FRAMEX .2619535 FRA-PER .1087051 FRA-TTO.1021157 GRC-KOR .1800705 GRC-MEX .1247106 GRC-PER .18072 GRCTTO .1599387 GTM-MEX .4249384 HND-MEX .2261586 HND-PAN .0566461 HND-USA .3663928 HUN-KOR .1592325 HUN-MEX .1159431 HUN-PER .2025293 HUN-TTO .1554878 IDN-JPN .1552601 IDN-KOR .1471916 IDN-NZL .0109401 IND-JPN .1367459 IND-KOR .1304406 IND-MYS .010156 IRL-ITA .4840032 IRL-KOR .1495507 IRL-MEX .0899191 IRLPER .191524 IRL-TTO .3411466 ITA-KOR .1639122 ITA-LTU .4711809 ITA-MEX .2488232 ITA-PER .1011334 ITA-TTO .0911465 JOR-USA .0120013 JPN-MEX .2857174 JPN-MYS .1201931 JPN-PER .1422789 JPN-PHL .1419505 JPN-THA $.1410456 \mathrm{JPN}-V N M .0708263 \mathrm{KEN}-\mathrm{RWA} .1772948 \mathrm{KEN}-\mathrm{TZA} .124701 \mathrm{KEN}-\mathrm{UGA} .0798281 \mathrm{KHM}-\mathrm{CHN} .0753998 \mathrm{KHM}-\mathrm{KOR}$ .085371 KHM-NZL .0050962 KOR-ESP .2125778 KOR-GBR .3020301 KOR-LTU .1090855 KOR-MYS .0893827 KOR-NLD .2229654 KOR-PER .09557 KOR-PHL .1746663 KOR-POL .2304362 KOR-PRT .1313413 KOR-ROU .1839261 KOR-SWE .2038998 KOR-THA .1319187 KOR-USA .3292094 KOR-VNM .0996835 LTU-MEX .0747448 LTU-PER .1680406 LTU-PRT .435878 LTU-TTO .2566926 MAR-USA .1308068 MEX-ESP .3188652 MEX-GBR .3067274 MEX-NIC .2153053 MEX-NLD .2165758 MEX-PER .1581092 MEX-POL .1992445 MEX-PRT.1008354 MEX-ROU .1275183 MEX-SWE .1650739 MYS-NZL .0124209 MYS-PAK .0250798 NIC-USA .4266197 NLD-PER .2468177 NLD-TTO .3520934 NZL-PHL .014855 NZL-THA .0095764 NZL-VNM .00547 OMN-USA .0111826 PAN-PER .0092904 PAN-USA .0993455 PER-ESP .3234374 PER-GBR .2872131 PER-POL .2580765 PER-PRT .1318392 PER-ROU .2243696 PER-SWE .2367958 PER-USA .4289208 POL-TTO .3386045 PRT-TTO .1124643 PRY-URY .2070715 PRY-VEN .098986 ROU-TTO .1969318 RWA-TZA .1060034 RWA-UGA $.1757244 S W E-T T O .2242941$ TTO-GBR .3436062 TZA-UGA .0396926 URY-VEN .1286946

Note: The figures are the associated estimated probabilities of negotiating an STA from the Probit estimation in Column 5 (Table 2) 
Table 4: Determinants of regulatory divergence in services markets

\begin{tabular}{|c|c|c|c|c|c|c|c|}
\hline \multicolumn{8}{|c|}{ PPML estimation: Dependent variable DREG } \\
\hline & (1) & (2) & (3) & (4) & (5) & (6) & (7) \\
\hline \multirow[t]{2}{*}{ Remote (-) } & $-0.034 * * *$ & & $-0.038^{* * *}$ & & $-0.033^{* * *}$ & & $-0.037^{* * * *}$ \\
\hline & $(0.004)$ & & $(0.004)$ & & $(0.004)$ & & $(0.004)$ \\
\hline \multirow[t]{2}{*}{ Natural (-) } & -0.003 & & 0.026 & & 0.001 & & 0.026 \\
\hline & $(0.018)$ & & $(0.019)$ & & $(0.018)$ & & $(0.019)$ \\
\hline \multirow[t]{2}{*}{ SRGDP $(+/-)$} & $-0.011^{* *}$ & & -0.011 & & $-0.014^{* * *}$ & & -0.014 \\
\hline & $(0.004)$ & & $(0.008)$ & & $(0.004)$ & & $(0.009)$ \\
\hline \multirow[t]{2}{*}{ DRGDP $(+)$} & $-0.060 * * *$ & & $-0.051^{* * *}$ & & $-0.059^{* * *}$ & & $-0.051 * * *$ \\
\hline & $(0.007)$ & & $(0.009)$ & & $(0.007)$ & & $(0.010)$ \\
\hline \multirow[t]{2}{*}{ DPCY $(+)$} & 0.042 & & 0.017 & & 0.038 & & 0.016 \\
\hline & $(0.032)$ & & $(0.034)$ & & $(0.031)$ & & $(0.034)$ \\
\hline \multirow[t]{2}{*}{ SQDPCY (+) } & 0.002 & & 0.008 & & 0.003 & & 0.008 \\
\hline & $(0.009)$ & & $(0.009)$ & & $(0.009)$ & & $(0.009)$ \\
\hline \multirow[t]{2}{*}{ DROWPCY (-) } & 0.021 & & 0.036 & & 0.027 & & 0.044 \\
\hline & $(0.027)$ & & $(0.029)$ & & $(0.027)$ & & $(0.029)$ \\
\hline \multirow[t]{2}{*}{ BTG (-) } & & $-0.015^{* * *}$ & $-0.012^{* * * *}$ & & & $-0.014^{* * *}$ & $-0.011^{* * *}$ \\
\hline & & $(0.002)$ & $(0.002)$ & & & $(0.002)$ & $(0.002)$ \\
\hline \multirow[t]{2}{*}{$\min \left(\right.$ Trade $\left.^{\mathrm{S}}\right)(+)$} & & $0.049^{* * * *}$ & $0.034^{* * *}$ & & & $0.048^{* * *}$ & $0.034^{* * *}$ \\
\hline & & $(0.008)$ & $(0.012)$ & & & $(0.008)$ & $(0.012)$ \\
\hline \multirow[t]{2}{*}{$\max \left(\operatorname{Trade}^{\mathrm{S}}\right)(+)$} & & -0.011 & 0.012 & & & -0.014 & 0.012 \\
\hline & & $(0.009)$ & $(0.013)$ & & & $(0.009)$ & $(0.013)$ \\
\hline \multirow[t]{2}{*}{ GTA_1980(-) } & & -0.308 & -0.127 & & & -0.311 & -0.145 \\
\hline & & $(0.191)$ & $(0.197)$ & & & $(0.190)$ & $(0.195)$ \\
\hline \multirow[t]{2}{*}{ Com_lang (-) } & & & & $-0.120^{* * *}$ & $-0.061 \#$ & $-0.075^{*}$ & -0.037 \\
\hline & & & & $(0.032)$ & $(0.032)$ & $(0.033)$ & $(0.033)$ \\
\hline \multirow[t]{2}{*}{ Com_col (-) } & & & & $-0.115^{*}$ & $-0.127^{* *}$ & $-0.121^{*}$ & $-0.113^{*}$ \\
\hline & & & & $(0.046)$ & $(0.045)$ & $(0.049)$ & $(0.049)$ \\
\hline \multirow[t]{2}{*}{ Com_law (-) } & & & & 0.035 & 0.031 & $0.041 \#$ & $0.043 \#$ \\
\hline & & & & $(0.023)$ & $(0.022)$ & $(0.024)$ & $(0.023)$ \\
\hline \multirow[t]{2}{*}{ Constant } & 0.060 & $-1.136^{* * * *}$ & $-0.488 \#$ & $-0.542^{* * * *}$ & 0.209 & $-1.043^{* * * *}$ & -0.377 \\
\hline & $(0.251)$ & $(0.209)$ & $(0.294)$ & $(0.012)$ & $(0.261)$ & $(0.216)$ & $(0.308)$ \\
\hline $\mathbf{N}$ & 5253 & 4796 & 4796 & 5253 & 5253 & 4796 & 4796 \\
\hline df_m & 7 & 4 & 11 & 3 & 10 & 7 & 14 \\
\hline $\mathrm{r}^{-}$ & 0.045 & 0.020 & 0.057 & 0.005 & 0.047 & 0.023 & 0.059 \\
\hline
\end{tabular}

Note: Levels of significance: $\# 10 \% * 5 \% * * 1 \% * * * 0.1 \%$; standard errors reported in brackets. The signs against the variables denote the expected signs of the coefficients. 
Table 5: Explaining the restrictiveness of services regimes in a dyad

\begin{tabular}{|c|c|c|c|c|c|c|c|}
\hline \multicolumn{8}{|c|}{ PPML estimation: Dependent variable SREG $^{\text {lev }}$} \\
\hline & (1) & (2) & (3) & (4) & (5) & (6) & (7) \\
\hline \multirow[t]{2}{*}{ Remote } & $0.009 * * *$ & & $0.011^{* * *}$ & & $0.009^{* * *}$ & & $0.010^{* * *}$ \\
\hline & $(0.002)$ & & $(0.002)$ & & $(0.002)$ & & $(0.002)$ \\
\hline \multirow{2}{*}{ Natural } & $-0.016 \#$ & & -0.006 & & $-0.023^{* *}$ & & -0.007 \\
\hline & $(0.009)$ & & $(0.009)$ & & $(0.009)$ & & $(0.009)$ \\
\hline \multirow[t]{2}{*}{ SRGDP } & $-0.012 * * *$ & & $-0.027 * * *$ & & $-0.009 * * *$ & & $-0.021 * * *$ \\
\hline & $(0.002)$ & & $(0.004)$ & & $(0.002)$ & & $(0.004)$ \\
\hline \multirow[t]{2}{*}{ DRGDP } & $-0.024 * * *$ & & $0.022 * * *$ & & $-0.023 * * *$ & & $0.021 * * *$ \\
\hline & $(0.003)$ & & $(0.005)$ & & $(0.003)$ & & $(0.005)$ \\
\hline \multirow[t]{2}{*}{ DPCY } & 0.025 & & $0.035^{*}$ & & $0.034^{*}$ & & $0.043 * *$ \\
\hline & $(0.016)$ & & $(0.016)$ & & $(0.016)$ & & $(0.016)$ \\
\hline \multirow[t]{2}{*}{ SQDPCY } & 0.005 & & 0.006 & & 0.003 & & 0.003 \\
\hline & $(0.004)$ & & $(0.004)$ & & $(0.004)$ & & $(0.004)$ \\
\hline \multirow[t]{2}{*}{ DROWPCY } & $0.121^{* * *}$ & & $0.098^{* * *}$ & & $0.122^{* * *}$ & & $0.098^{* * *}$ \\
\hline & $(0.014)$ & & $(0.015)$ & & $(0.014)$ & & $(0.015)$ \\
\hline \multirow[t]{2}{*}{ BTG } & & $-0.004 * * *$ & $-0.004 * * *$ & & & $-0.005^{* * * *}$ & $-0.004 * * *$ \\
\hline & & $(0.001)$ & $(0.001)$ & & & $(0.001)$ & $(0.001)$ \\
\hline \multirow[t]{2}{*}{$\min \left(\right.$ Trade $\left.^{\mathrm{S}}\right)$} & & $0.058^{* * *}$ & $0.100^{* * *}$ & & & $0.059 * * *$ & $0.096^{* * *}$ \\
\hline & & $(0.004)$ & $(0.005)$ & & & $(0.004)$ & $(0.005)$ \\
\hline \multirow[t]{2}{*}{$\max \left(\right.$ Trade $\left.^{\mathrm{S}}\right)$} & & $-0.037^{* * * *}$ & $-0.047^{* * * *}$ & & & $-0.027^{* * * *}$ & $-0.044 * * *$ \\
\hline & & $(0.004)$ & $(0.006)$ & & & $(0.004)$ & $(0.006)$ \\
\hline \multirow[t]{2}{*}{ GTA_1980 } & & $-0.321 * * *$ & $-0.333 * * *$ & & & $-0.341^{* * * *}$ & $-0.346^{* * * *}$ \\
\hline & & $(0.060)$ & $(0.073)$ & & & $(0.058)$ & $(0.071)$ \\
\hline \multirow[t]{2}{*}{ Com_lang } & & & & -0.009 & 0.002 & -0.015 & $-0.027 \#$ \\
\hline & & & & $(0.016)$ & $(0.016)$ & $(0.016)$ & $(0.015)$ \\
\hline \multirow[t]{2}{*}{ Com_col } & & & & $0.183^{* * * *}$ & $0.118^{* * *}$ & $0.209^{* * * *}$ & $0.129 * * *$ \\
\hline & & & & $(0.019)$ & $(0.019)$ & $(0.020)$ & $(0.019)$ \\
\hline \multirow[t]{2}{*}{ Com_law } & & & & $0.054^{* * * *}$ & $0.063^{* * * *}$ & $0.063^{* * * *}$ & $0.067^{* * * *}$ \\
\hline & & & & $(0.012)$ & $(0.011)$ & $(0.012)$ & $(0.011)$ \\
\hline \multirow[t]{2}{*}{ Constant } & $4.339 * * *$ & $3.756^{* * * *}$ & $4.133^{* * * *}$ & 4.009 ***** & $4.082 * * *$ & 3.482 **** & $3.829 * * *$ \\
\hline & $(0.124)$ & $(0.106)$ & $(0.139)$ & $(0.006)$ & $(0.128)$ & $(0.109)$ & $(0.146)$ \\
\hline$\overline{\mathbf{N}}$ & 5253 & 4796 & 4796 & 5253 & 5253 & 4796 & 4796 \\
\hline df_m & 7 & 4 & 11 & 3 & 10 & 7 & 14 \\
\hline $\mathrm{r} 2$ & 0.078 & 0.043 & 0.141 & 0.022 & 0.092 & 0.07 & 0.156 \\
\hline
\end{tabular}

Note: Levels of significance: \#10\%*5\%**1\%***0.1\%; standard errors reported in brackets. 
Table A1: List of countries

Albania, Argentina, Armenia, Australia, Austria, Burundi, Belgium, Bangladesh, Bulgaria, Bahrain, Belarus, Bolivia, Brazil, Botswana, Canada, Chile, China, Cote d'Ivoire, Cameroon, Congo (Democratic Republic), Colombia, Costa Rica, Czech Republic, Germany, Denmark, Dominican Republic, Algeria, Ecuador, Egypt, Spain, Ethiopia, Finland, France, Great Britain, Georgia, Ghana, Greece, Guatemala, Honduras, Hungary, Indonesia, India, Ireland, Iran, Italy, Jordan, Japan, Kazakhstan, Kenya, Kyrgyz Republic, Cambodia, South Korea, Kuwait, Lebanon, Sri Lanka, Lesotho, Lithuania, Morocco, Madagascar, Mexico, Mali, Mongolia, Mozambique, Mauritius, Malawi, Malaysia, Namibia, Nigeria, Nicaragua, the Netherlands, Nepal, New Zealand, Oman, Pakistan, Panama, Peru, the Philippines, Poland, Portugal, Paraguay, Qatar, Romania, Russian Federation, Rwanda, Saudi Arabia, Senegal, Sweden, Thailand, Trinidad \& Tobago, Tunisia, Turkey, Tanzania, Uganda, Ukraine, Uruguay, USA, Uzbekistan, Venezuela, Vietnam, Yemen, South Africa, Zambia, Zimbabwe 
Table A2: Summary statistics

\begin{tabular}{|c|c|c|c|c|c|}
\hline Variable & Obs & Mean & Std. Dev. & Min & Max \\
\hline \multicolumn{6}{|c|}{ Geography } \\
\hline Distance $(\mathrm{km})$ & 5253 & 7619.9 & 4313.8 & 139.0 & 19812.0 \\
\hline NAT & 5253 & -8.7 & 0.8 & -9.9 & -4.9 \\
\hline REM & 5253 & 1.9 & 3.7 & 0.0 & 9.5 \\
\hline \multicolumn{6}{|c|}{ Economic } \\
\hline rgdp_p (USD bn) & 5253 & 291.0 & 832.0 & 1.0 & 5700.0 \\
\hline rgdp_r (USD bn) & 5253 & 206.0 & 437.0 & 1.0 & 5700.0 \\
\hline SRGDP & 5253 & 49.2 & 2.5 & 42.2 & 57.8 \\
\hline DRGDP & 5253 & 2.1 & 1.5 & 0.0 & 8.7 \\
\hline pcrgdp_p (USD) & 5253 & 8210.5 & 9900.0 & 404.4 & 59557.4 \\
\hline pcrgdp_r (USD) & 5253 & 8437.7 & 9047.7 & 404.4 & 59557.4 \\
\hline DPCY & 5253 & 1.5 & 1.0 & 0.0 & 5.0 \\
\hline SQDPCY & 5253 & 3.2 & 3.9 & 0.0 & 24.9 \\
\hline DROWPCY & 5253 & 1.1 & 0.5 & 0.0 & 2.7 \\
\hline \multicolumn{6}{|c|}{ Institutional } \\
\hline stri_r & 5253 & 27.7 & 15.1 & 6.2 & 88.2 \\
\hline stri_p & 5253 & 29.0 & 14.6 & 6.2 & 88.2 \\
\hline DREG & 5253 & 0.6 & 0.4 & 0.0 & 2.7 \\
\hline SREG & 5253 & 6.4 & 0.7 & 4.2 & 8.7 \\
\hline SREG $^{\text {lev }}$ & 5253 & 56.7 & 20.9 & 17.1 & 153.9 \\
\hline Com_lang & 5253 & 0.1 & 0.3 & 0.0 & 1.0 \\
\hline Com_col & 5253 & 0.1 & 0.2 & 0.0 & 1.0 \\
\hline Com_law & 5253 & 0.3 & 0.5 & 0.0 & 1.0 \\
\hline STA & 5253 & 0.1 & 0.3 & 0.0 & 1.0 \\
\hline \multicolumn{6}{|c|}{ Political economy } \\
\hline Services trade_r (real USD bn) & 5091 & 3.9 & 8.5 & 0.0 & 54.0 \\
\hline Services trade_p (real USD bn) & 5060 & 4.8 & 10.6 & 0.0 & 54.0 \\
\hline BTG (real USD bn) & 4799 & 0.2 & 1.3 & 0.0 & 50.5 \\
\hline GTA_1980 & 5253 & 0.002 & 0.044 & 0 & 1 \\
\hline $\min \left(\right.$ Trade $\left.^{\mathrm{Ser}}\right)$ & 5248 & 19.7 & 1.4 & 16.6 & 24.7 \\
\hline $\max \left(\operatorname{Trade}^{\mathrm{Ser}}\right)$ & 5248 & 21.6 & 1.6 & 16.6 & 24.7 \\
\hline
\end{tabular}


Table A3: Robustness results from estimating equation (1)

\begin{tabular}{|c|c|c|c|c|c|c|c|}
\hline \multicolumn{8}{|c|}{ Probit estimation: Dependent variable STA } \\
\hline & (1) & (2) & (3) & (4) & (5) & $(6)$ & (7) \\
\hline \multirow[t]{2}{*}{ Remote (+) } & 0.015 & & 0.010 & & $0.031^{*}$ & & $0.030^{*}$ \\
\hline & $(0.012)$ & & $(0.012)$ & & $(0.013)$ & & $(0.014)$ \\
\hline \multirow[t]{2}{*}{ Natural $(+)$} & $0.167^{* *}$ & & 0.076 & & $0.189 * *$ & & $0.133^{*}$ \\
\hline & $(0.055)$ & & $(0.061)$ & & $(0.062)$ & & $(0.067)$ \\
\hline \multirow[t]{2}{*}{ SRGDP $(+)$} & $0.120^{* * *}$ & & 0.048 & & $0.125^{* * *}$ & & 0.016 \\
\hline & $(0.015)$ & & $(0.029)$ & & $(0.016)$ & & $(0.033)$ \\
\hline \multirow[t]{2}{*}{ DRGDP (-) } & $-0.066^{*}$ & & $-0.187^{* * *}$ & & $-0.114 * * *$ & & $-0.174 * * *$ \\
\hline & $(0.027)$ & & $(0.037)$ & & $(0.029)$ & & $(0.041)$ \\
\hline \multirow[t]{2}{*}{$\mathrm{DPCY}(+)$} & 0.142 & & 0.057 & & 0.196 & & 0.102 \\
\hline & $(0.128)$ & & $(0.131)$ & & $(0.136)$ & & $(0.141)$ \\
\hline \multirow{2}{*}{ SQDPCY $(+)$} & $-0.086^{*}$ & & $-0.072 \#$ & & -0.067 & & -0.050 \\
\hline & $(0.041)$ & & $(0.041)$ & & $(0.043)$ & & $(0.044)$ \\
\hline \multirow[t]{2}{*}{ DROWPCY (-) } & -0.089 & & -0.138 & & -0.021 & & -0.150 \\
\hline & $(0.084)$ & & $(0.092)$ & & $(0.097)$ & & $(0.106)$ \\
\hline \multirow[t]{2}{*}{ BTG (-) } & & $0.049 * * *$ & $0.041 * * *$ & & & $0.055^{* * *}$ & 0.039 *** \\
\hline & & $(0.008)$ & $(0.009)$ & & & $(0.009)$ & $(0.010)$ \\
\hline \multirow[t]{2}{*}{$\min \left(\operatorname{Trade}^{\mathrm{S}}\right)(+)$} & & -0.033 & $-0.179^{* * *}$ & & & 0.036 & -0.039 \\
\hline & & $(0.028)$ & $(0.041)$ & & & $(0.030)$ & $(0.047)$ \\
\hline \multirow[t]{2}{*}{$\max \left(\operatorname{Trade}^{\mathrm{S}}\right)(+)$} & & 0.012 & $0.166^{* * * *}$ & & & -0.040 & $0.136^{*}$ \\
\hline & & $(0.029)$ & $(0.050)$ & & & $(0.032)$ & $(0.056)$ \\
\hline \multirow{2}{*}{ SREG (-) } & & & & $-0.499 * * *$ & $-0.588^{* * *}$ & $-0.573^{* * *}$ & $-0.580^{* * *}$ \\
\hline & & & & $(0.054)$ & $(0.061)$ & $(0.061)$ & $(0.066)$ \\
\hline \multirow[t]{2}{*}{ DREG (-) } & & & & $-0.532 * * *$ & $-0.497^{* * *}$ & $-0.508^{* * *}$ & $-0.477^{* * *}$ \\
\hline & & & & $(0.100)$ & $(0.107)$ & $(0.108)$ & $(0.111)$ \\
\hline \multirow[t]{2}{*}{ Com_lang $(+)$} & & & & $0.287^{* * *}$ & $0.275^{*}$ & 0.163 & 0.148 \\
\hline & & & & $(0.101)$ & $(0.109)$ & $(0.107)$ & $(0.116)$ \\
\hline \multirow[t]{2}{*}{ Com_col (+) } & & & & -0.123 & -0.056 & 0.057 & 0.023 \\
\hline & & & & $(0.182)$ & $(0.203)$ & $(0.200)$ & $(0.216)$ \\
\hline \multirow[t]{2}{*}{ Com_law $(+)$} & & & & -0.111 & $-0.153 \#$ & -0.117 & -0.139 \\
\hline & & & & $(0.083)$ & $(0.092)$ & $(0.089)$ & $(0.095)$ \\
\hline \multirow[t]{2}{*}{ Constant } & $-6.085^{* * * *}$ & $-1.991^{* * *}$ & $-3.481^{* * * *}$ & 1.589 **** & $-2.356^{*}$ & $1.522 \#$ & 0.173 \\
\hline & $(0.835)$ & $(0.720)$ & $(0.970)$ & $(0.332)$ & $(0.974)$ & $(0.852)$ & (1.139) \\
\hline$\overline{\mathbf{N}}$ & 4975 & 4519 & 4519 & 4975 & 4975 & 4519 & 4519 \\
\hline df_m & 7 & 3 & 10 & 5 & 12 & 8 & 15 \\
\hline Pseudo-r2 & 0.078 & 0.047 & 0.106 & 0.097 & 0.175 & 0.145 & 0.188 \\
\hline
\end{tabular}

Note: Levels of significance: \#10\%* $5 \% * * 1 \% * * * 0.1 \%$; standard errors reported in brackets. The signs against the variables denote the expected signs of the coefficients. Sample restricted to dyads for which an STA entered in force in the year 2008 and beyond. 
Table A4: Robustness results from estimating equation (2)

\begin{tabular}{|c|c|c|c|c|c|c|c|}
\hline \multicolumn{8}{|c|}{ PPML estimation: Dependent variable DREG } \\
\hline & (1) & (2) & (3) & (4) & (5) & (6) & (7) \\
\hline \multirow[t]{2}{*}{ Remote (-) } & $-0.030 * * *$ & & $-0.033^{* * *}$ & & $-0.029 * * *$ & & $-0.032 * * *$ \\
\hline & $(0.004)$ & & $(0.004)$ & & $(0.004)$ & & $(0.004)$ \\
\hline \multirow[t]{2}{*}{ Natural (-) } & 0.015 & & $0.049^{*}$ & & 0.022 & & $0.051^{*}$ \\
\hline & $(0.019)$ & & $(0.020)$ & & $(0.019)$ & & $(0.020)$ \\
\hline \multirow[t]{2}{*}{$\operatorname{SRGDP}(+/-)$} & -0.005 & & -0.008 & & $-0.008 \#$ & & -0.012 \\
\hline & $(0.004)$ & & $(0.008)$ & & $(0.004)$ & & $(0.009)$ \\
\hline \multirow[t]{2}{*}{ DRGDP $(+)$} & $-0.064 * * *$ & & $-0.057^{* * *}$ & & $-0.063^{* * *}$ & & $-0.057 * * *$ \\
\hline & $(0.007)$ & & $(0.009)$ & & $(0.007)$ & & $(0.010)$ \\
\hline \multirow[t]{2}{*}{$\operatorname{DPCY}(+)$} & 0.027 & & -0.002 & & 0.021 & & -0.005 \\
\hline & $(0.032)$ & & $(0.034)$ & & $(0.032)$ & & $(0.034)$ \\
\hline \multirow[t]{2}{*}{ SQDPCY $(+)$} & 0.004 & & 0.010 & & 0.005 & & 0.011 \\
\hline & $(0.009)$ & & $(0.009)$ & & $(0.009)$ & & $(0.009)$ \\
\hline \multirow[t]{2}{*}{ DROWPCY (-) } & 0.035 & & $0.047 \#$ & & 0.043 & & $0.055 \#$ \\
\hline & $(0.027)$ & & $(0.028)$ & & $(0.027)$ & & $(0.028)$ \\
\hline \multirow[t]{2}{*}{ BTG (-) } & & $-0.014^{* * * *}$ & $-0.013^{* * *}$ & & & $-0.013^{* * *}$ & $-0.012 * * *$ \\
\hline & & $(0.002)$ & $(0.002)$ & & & $(0.002)$ & $(0.002)$ \\
\hline \multirow[t]{2}{*}{$\min \left(\right.$ Trade $\left.^{\mathrm{S}}\right)(+)$} & & $0.061^{* * * *}$ & $0.037^{* *}$ & & & $0.059^{* * *}$ & $0.039 * * *$ \\
\hline & & $(0.009)$ & $(0.012)$ & & & $(0.009)$ & $(0.012)$ \\
\hline \multirow[t]{2}{*}{$\max \left(\right.$ Trade $\left.^{\mathrm{S}}\right)(-)$} & & -0.006 & 0.021 & & & -0.011 & 0.021 \\
\hline & & $(0.009)$ & $(0.013)$ & & & $(0.009)$ & $(0.013)$ \\
\hline \multirow[t]{2}{*}{ Com_lang (-) } & & & & $-0.121^{* * *}$ & $-0.075^{*}$ & $-0.085^{*}$ & -0.055 \\
\hline & & & & $(0.033)$ & $(0.033)$ & $(0.034)$ & $(0.034)$ \\
\hline \multirow[t]{2}{*}{ Com_col (-) } & & & & $-0.137^{* * *}$ & $-0.147^{* * *}$ & $-0.130^{* * *}$ & $-0.130^{* * *}$ \\
\hline & & & & $(0.046)$ & $(0.046)$ & $(0.049)$ & $(0.049)$ \\
\hline \multirow[t]{2}{*}{ Com_law (-) } & & & & 0.032 & 0.031 & 0.039 & $0.044 \#$ \\
\hline & & & & $(0.023)$ & $(0.023)$ & $(0.024)$ & $(0.024)$ \\
\hline \multirow[t]{2}{*}{ Constant } & -0.057 & $-1.440^{* * * *}$ & $-0.670^{*}$ & $-0.518^{* * *}$ & 0.129 & $-1.333^{* * * *}$ & $-0.509 \#$ \\
\hline & $(0.253)$ & $(0.214)$ & $(0.296)$ & $(0.013)$ & $(0.262)$ & $(0.221)$ & $(0.309)$ \\
\hline$\overline{\mathbf{N}}$ & 4975 & 4519 & 4519 & 4975 & 4975 & 4519 & 4519 \\
\hline df_m & 7 & 3 & 10 & 3 & 10 & 6 & 13 \\
\hline $\mathrm{r}^{-}$ & 0.035 & 0.018 & 0.047 & 0.006 & 0.038 & 0.022 & 0.050 \\
\hline
\end{tabular}

Note: Levels of significance: \#10\%*5\%**1\%***0.1\%; standard errors reported in brackets. The signs against the variables denote the expected signs of the coefficients. Sample restricted to dyads for which an STA entered in force in the year 2008 and beyond. 
Table A5: Robustness results from estimating equation (3)

\begin{tabular}{|c|c|c|c|c|c|c|c|}
\hline \multicolumn{8}{|c|}{ PPML estimation: Dependent variable SREG ${ }^{\text {lev }}$} \\
\hline & (1) & (2) & (3) & (4) & (5) & (6) & (7) \\
\hline \multirow[t]{2}{*}{ Remote } & $0.013^{* * *}$ & & $0.016^{* * *}$ & & $0.013^{* * *}$ & & $0.015^{* * *}$ \\
\hline & $(0.002)$ & & $(0.002)$ & & $(0.002)$ & & $(0.002)$ \\
\hline \multirow[t]{2}{*}{ Natural } & $0.021^{*}$ & & $0.036^{* * *}$ & & 0.014 & & $0.036^{* * *}$ \\
\hline & $(0.009)$ & & $(0.009)$ & & $(0.009)$ & & $(0.009)$ \\
\hline \multirow[t]{2}{*}{ SRGDP } & -0.003 & & $-0.021 * * *$ & & -0.001 & & $-0.018^{* * *}$ \\
\hline & $(0.002)$ & & $(0.004)$ & & $(0.002)$ & & $(0.004)$ \\
\hline \multirow[t]{2}{*}{ DRGDP } & $-0.028 * * *$ & & $0.014 * *$ & & $-0.027 * * *$ & & $0.014^{* *}$ \\
\hline & $(0.003)$ & & $(0.005)$ & & $(0.003)$ & & $(0.004)$ \\
\hline \multirow[t]{2}{*}{ DPCY } & -0.002 & & 0.003 & & 0.005 & & 0.009 \\
\hline & $(0.016)$ & & $(0.016)$ & & $(0.016)$ & & $(0.016)$ \\
\hline \multirow[t]{2}{*}{ SQDPCY } & $0.009^{*}$ & & $0.010^{*}$ & & 0.007 & & $0.009^{*}$ \\
\hline & $(0.004)$ & & $(0.004)$ & & $(0.004)$ & & $(0.004)$ \\
\hline \multirow[t]{2}{*}{ DROWPCY } & $0.143^{* * *}$ & & $0.114 * * *$ & & $0.143^{* * *}$ & & $0.112^{* * *}$ \\
\hline & $(0.013)$ & & $(0.014)$ & & $(0.013)$ & & $(0.014)$ \\
\hline BTG & & $\begin{array}{c}-0.003^{* * * *} \\
(0.001)\end{array}$ & $\begin{array}{c}-0.005^{* * * *} \\
(0.001)\end{array}$ & & & $\begin{array}{c}-0.004^{* * *} \\
(0.001)\end{array}$ & $\begin{array}{c}-0.005^{* * * *} \\
(0.001)\end{array}$ \\
\hline $\min \left(\right.$ Trade $\left.^{\mathrm{Ser}}\right)$ & & $\begin{array}{c}0.067^{* * * *} \\
(0.004)\end{array}$ & $\begin{array}{c}0.103^{* * * *} \\
(0.005)\end{array}$ & & & $\begin{array}{c}0.069^{* * * *} \\
(0.004)\end{array}$ & $\begin{array}{c}0.101^{* * * *} \\
(0.005)\end{array}$ \\
\hline $\max \left(\right.$ Trade $\left.^{\text {Ser }}\right)$ & & $\begin{array}{c}-0.035^{* * *} \\
(0.004)\end{array}$ & $\begin{array}{c}-0.034 * * * \\
(0.006)\end{array}$ & & & $\begin{array}{c}-0.025^{* * * *} \\
(0.004)\end{array}$ & $\begin{array}{c}-0.031^{* * * *} \\
(0.006)\end{array}$ \\
\hline Com_lang & & & & $\begin{array}{l}-0.009 \\
(0.016)\end{array}$ & $\begin{array}{l}-0.014 \\
(0.016)\end{array}$ & $\begin{array}{l}-0.024 \\
(0.016)\end{array}$ & $\begin{array}{c}-0.052^{* * * *} \\
(0.015)\end{array}$ \\
\hline Com_col & & & & $\begin{array}{c}0.167^{* * * * *} \\
(0.019)\end{array}$ & $\begin{array}{c}0.089^{* * * *} \\
(0.019)\end{array}$ & $\begin{array}{c}0.201^{* * * *} \\
(0.020)\end{array}$ & $\begin{array}{c}0.105^{* * * *} \\
(0.019)\end{array}$ \\
\hline Com_law & & & & $\begin{array}{c}0.051^{* * * * *} \\
(0.012)\end{array}$ & $\begin{array}{c}0.057^{* * * *} \\
(0.011)\end{array}$ & $\begin{array}{c}0.060^{* * * *} \\
(0.012)\end{array}$ & $\begin{array}{c}0.062^{* * * *} \\
(0.011)\end{array}$ \\
\hline Constant & $\begin{array}{c}4.238^{* * * *} \\
(0.122)\end{array}$ & $\begin{array}{c}3.510^{* * * *} \\
(0.107)\end{array}$ & $\begin{array}{c}3.937^{* * * *} \\
(0.136)\end{array}$ & $\begin{array}{c}4.027^{* * * * *} \\
(0.006)\end{array}$ & $\begin{array}{c}4.046^{* * * *} \\
(0.126)\end{array}$ & $\begin{array}{c}3.256^{* * * *} \\
(0.110)\end{array}$ & $\begin{array}{c}3.731^{* * * * *} \\
(0.143)\end{array}$ \\
\hline $\mathbf{N}$ & 4975 & 4519 & 4519 & 4975 & 4975 & 4519 & 4519 \\
\hline df_m & 7 & 3 & 10 & 3 & 10 & 6 & 13 \\
\hline r2 & 0.102 & 0.051 & 0.172 & 0.020 & 0.111 & 0.076 & 0.183 \\
\hline
\end{tabular}

Note: Levels of significance: \#10\%*5\%**1\%***0.1\%; standard errors reported in brackets. Sample restricted to dyads for which an STA entered in force in the year 2008 and beyond. 